\title{
Prevalence of bovine trypanosomosis in Wemberma district of West Gojjam zone, North West Ethiopia-
}

\author{
Yehunie Bishaw ${ }^{1}$, Wudu Temesgen ${ }^{2}$, Nuria Yideg $^{3}$, Sefinew Alemu ${ }^{2}$ \\ ${ }^{1}$ Wemberma district agricultural office, west Gojjam, Amhar national regional state. \\ ${ }^{2}$ Faculty of Veterinary Medicine, University of Gondar, Gondar, \\ ${ }^{3}$ Bahir Dar regional veterinary laboratory, Bahir Dar
}

Corresponding author: Wudu Temesegen, Faculty of veterinary medicine, university of Gondar, Gondar,e-mail temesgenha@yahoo.com

\begin{abstract}
A cross-sectional survey of bovine trypanosomosis was carried out in Wemberma district of west Gojjam zone, North West Ethiopia. From three peasant associations in the district (one from the midland and two from lowland), 384 cattle were randomly selected and examined for trypanosomosis. The prevalence of the disease as determined by buffy coat techinque was $7.81(95 \% \mathrm{CI}=5.11-10.5 \%)$. Trypanosoma vivax and $T$. congolense were detected from buffy coat positive samples. Among the total of 30 cases of trypanosome infections detected 24(80\%) of the infections were due to T.vivax and the rest $6(20 \%)$ were due to T. congolense. No statistically significant associations $(\mathrm{P}>0.05)$ were observed between the disease and potential risk factors like age, sex and agroecology. However, when the different species of trypanosomes were considered, $T$. congolense infections were found only in the lowland. A significant association was observed $(\mathrm{P}<0.05)$ between the disease positivity and body condition score. When the mean packed cell volume of trypanosome infected animals was compared with that of non infected animals, it was significantly lower $(\mathrm{P}<0.05)$ in the infected animals, and the reduction was significantly lower $(\mathrm{p}<0.05)$ for $T$. congolense infection as compared with $T$. vivax infection. In conclusion, trypanosomsis was found to be important disease in the study area, and T. vivax was the more prevalent species and $T$. congolense with more negative impact in mean packed cell volume of affected animals.
\end{abstract}

Keywords: Bovine, PCV, Prevalence, Trypanosomes, Wemberma

http://dx.doi.org/10.4314/evj.v16i2.4 


\section{Introduction}

Bovine trypanosomosis is one of the most prevalent and important disease in Ethiopia limiting livestock productivity and agricultural development (Abebe and Jobre, 1996). Once it was estimated that about $38 \%$ of the national cattle herd was affected or at risk of trypansomosis infection (Zelleke Dagnachew, 1982). The disease is very economical because of it highest prevalence in the most arable and fertile land with high potential for agricultural development in the South West and North West part of the country along the great river basins of Abay, Omo, Ghibe and Baro which are infested with vector tsetse fly. There are also studies which showed the disease to be equally important in non-tsetse infested highland part of the country (Cherenet et al., 2006). Previous Studies revealed the prevalence of the disease in many districts of Amhara region with obvious economical consequences (Shimels Dagnachew et al., 2005; Alekaw Sinishaw et al., 2006; Adane Mihret and Gezahagn Mamo, 2008; Solomon Mekuria and Fitta Gadissa, 2011; Mollalign Bitew et al., 2011). The problem was seen to be prominent in districts bordering the Abay river basin where both cyclically and mechanically transmitted trypanosomosis were reported. Wemberma district of West Gojjam zone is one such district where there was serious complaint of the disease. But no previous study had covered the district to show the situation of the disease. The present study was, therefore, conducted in the district with objective of determining the prevalence of the disease, identifying the species of Trypanosoma and assessing of risk factors of the disease.

\section{Materials and methods}

\section{Study area and study animals}

The study was conducted in Wemberma district, West Gojjam zone of Amhara region, North West Ethiopia. Wemberma district is bordered on the south by river Abbay which separates it from Ormoyia regional state, on the west by Bure district, on the north and north east by Ankesha district and on the east by Guanga district.

The district is the land of diverse topography with altitude ranging from 800 to 2212 meter above sea level (masl). Based on altitude it is divided in to 2 agro-ecological zones as midland ('woynadega') 47\% and lowland ('Kola') 53\% respectively. The area has a rainy season (June to September) and a longer dry season (October to May) with mean annual rain fall of $1115 \mathrm{~mm}$. The land is covered by different vegetation types namely savanna grass lands, forest and 
bush lands. The annual mean temperature for most parts of the district is 14 $-26{ }^{\circ} \mathrm{c}$ (OWWARD, 2004)

The livestock population of the district comprises about 74637 cattle, 30257 sheep, 4391 goats 9727 equines, 88189 poultry and 5972 beehives. The study animals were indigenous zebu cattle of all age group. The farming system in the areas is a crop-livestock mixed farming and the cattle involved in the study were maintained under traditional management system (OWWARD, 2004).

\section{Study design and sampling}

The study was a cross-sectional study and samples were collected in the months of November and December 2009. Animals were randomly selected from three peasant associations (Woynma Assess, Gomer dond, and Wogedad Ayshal) that were assumed to represent the lowland and midland part of the study area. The first two have majority of the land below 1500 masl and were considered as lowland and the later has an altitude above 1500 masl and considered as midland for this study. A total of 384 animals were examined for the study. The sample size was determined based on sample size determination for prevalence study from infinite population with $95 \%$ confidence level, $5 \%$ of desired absolute precession and expected prevalence of 50\% (Thrusfield, 2005). During sampling sex, age and body condition of animals were recorded. The body condition score was categorized as poor and good taking the middle point as a border in the 9 scale scores of Nicholson and Butterworth (1986) method of body condition scoring for zebu cattle.

\section{Sample collection, Packed cell volume determination and parasite detection}

Blood samples were collected by puncturing of the marginal ear vein of each animal with a lancet and drawn directly in to heparinized capillary tube. The packed cell volume (PCV) was measured after the heparinized capillary tubes containing blood were centrifuged for $5 \mathrm{~min}$ at $12,000 \mathrm{rpm}$ in microhematocrit centrifuge. The capillary tube was then cut, the buffy coat and upper most layers of the red blood cells discharged onto a microscopic slide, covered with cover slip, and examined under microscope for the presence of motile Trypanosomes (Paris et al., 1982; MORAD, 2005). Thin smear were made and stained with Gimsa staining technique from buffy coat positive samples for identification of Trypanosoma species. 


\section{Data management and analysis}

Data on individual animals and parasitological examination result was entered into MS-Excel spread sheets program. The prevalence of trypanosomosis and PCV, with corresponding $95 \%$ confidence intervals, were determined for different categories of study animals. The trypanosome infection rates with different variables like altitude, age and sex and body condition score were compared by chi- square test. The mean PCV of infected and non infected animals were compared using student t-test. Intercooled Stata 7.0 (Stata corporation 1985-2001) software was used to conduct the statistical analyses.

\section{Results}

\section{Parasitological Findings}

From the total of 384 cattle examined with a Buffy coat technique, 30 were positive for trypanosomes giving an overall prevalence of $7.81 \%(95 \% \mathrm{CI}=5.11 \%$ - 10.5\%). Trypnosoma vivax and Trypnosoma congolense were the Trypnosoma species identified by Giemsa stained thin blood smear examination. Among the total of 30 cases of trypanosome infections detected $24(80 \%)$ of the infections were due to T. vivax and the rest $6(20 \%)$ were due to $T$. congolense. The prevalence of Trypanosoma species in cattle within different altitude area during the study period is shown in Table 1.

No statistically significant difference $(\mathrm{P}=0.1070)$ was observed when overall prevalence of trypanosome infection was compared with different altitude (Table 1). However when the different species were considered, T. congolense infection was observed only in lowland areas of the district.

Table 1. The prevalence of Trypanosoma species at different altitudes in the study area

\begin{tabular}{|c|c|c|c|c|}
\hline \multirow[t]{2}{*}{ Altitude } & \multicolumn{2}{|c|}{ Species of Trypanosma } & \multirow{2}{*}{$\begin{array}{c}\text { Total } \\
\text { prevalence }\end{array}$} & \multirow[t]{2}{*}{ P-Value } \\
\hline & T. vivax & T. congolense & & \\
\hline Midland & $6(4.6 \%)$ & 0 & $4.7 \%$ & $0=1070$ \\
\hline Lowland & $18(7.0 \%)$ & $6(2.3 \%)$ & $11.72 \%$ & \\
\hline Total & $24(6.77 \%)$ & $6(1.5 \%)$ & $7.81 \%$ & \\
\hline
\end{tabular}


The association of trypanosomes infection with different potential risk factors as analyzed by chi-square and Fisher's exact tests is indicated in Table 2.

No significant association was found between trypanosome infection, and age and sex of animals. But statistically significant association (P.0060) was observed between trypanosome infection and body condition score (Table 2).

Table 2. Prevalence of trypanosomosis infection with different potential risk factors

\begin{tabular}{lccc}
\hline Potential risk factors & $\begin{array}{c}\text { No. of animals } \\
\text { examined }\end{array}$ & $\begin{array}{c}\text { Infected animals } \\
\text { (prevalence) }\end{array}$ & P-Value \\
\hline age & 48 & $1(2.01 \%)$ & 0.1140 \\
Young((<2 years) & 336 & $29(8.6 \%)$ & \\
adults (>2 years) & & & 0.4270 \\
Sex & 141 & $9(6.40 \%)$ & \\
Female & 243 & $21(8.6 \%)$ & 0.0060 \\
male & 124 & $3(2.42 \%)$ & \\
Body condition & 260 & $27(10.4 \%)$ & \\
Good & & & \\
poor & & & \\
\hline
\end{tabular}

\section{Haematological Findings}

The PCV of individual animals was measured for the assessment of degree of anemia. A mean PCV of $21.16 \%$ and $27.09 \%$ was found for infected animals and non infected animals respectively. The difference was statistically significant $(\mathrm{P}=0.000)$ (Table 3$)$.

Table 3. Mean PCV of infected and non - infected animals in the study sites

\begin{tabular}{lllll}
\hline Status of infection & Number of animals & Mean PCV (\%) & $\mathbf{9 5 \%}$ CI(\%) & p- value \\
\hline Infected & 30 & 21.16 & $20.00-22.32$ & 0.0000 \\
Non- infected & 354 & 27.09 & $26.82-27.35$ & \\
\hline
\end{tabular}

Both Trypanosoma vivax and Trypanosoma congolense infections caused reduction of PCV in infected animals. Trypanosoma congolense caused statistically significant reduction in PCV $(\mathrm{P}=0.0000)$ as compared to Trypanosoma vivax infection (Table 4). 
Table 4. Comparison of mean PCV of infected cattle within different species of Trypanosoma:

\begin{tabular}{lllll}
\hline $\begin{array}{l}\text { Species of } \\
\text { Trypanosoma }\end{array}$ & $\begin{array}{l}\text { Number of } \\
\text { Infected }\end{array}$ & Mean PCV (\%) & $\mathbf{9 5 \% C I ~ ( \% )}$ & p- value \\
\hline T. vivax & 24 & 22.25 & $21.23-23.26$ & 0.0000 \\
T. congolense & 6 & 16.83 & $15.60-18.06$ & \\
\hline
\end{tabular}

\section{Discussion}

The $7.81 \%$ prevalence of bovine trypanosomosis found in this study was in the lower border of the range of prevalence reports by previous studies in the neighboring districts of west Gojjam zone and other areas of Amhara region. Prevalence reports from these previous studies varied from $6 \%$ in the mechanically transmitted trypanosomosis areas bordering lake Tana to $17 \%$ in mixed infection areas of districts bordering Abay basin (Shimelis Dagnachew et al., 2005; Alekaw Sinshaw et al., 2006; Adane Mihret and Gezahagn Mamo, 2008; Solomon Mekuria and Fitta Gadissa, 2011; Mollalign Bitew et al., 2011).

T.vivax and T. congolense were the species detected from infected animals. On the midland part of the study area only T.vivax was found. Unlike most of reports in the mixed infection area, majority of infections in the present study area were due to T.vivax including in the lowland areas nearer to the Abay valley where the tsetse fly vector is known to exist (Shimelis Dagnachew et al., 2005). No T. congolense was detected from animals in areas considered as midland indicating the possible absence of the tsetse fly vector in that part of the study district.

The associations of the disease with age, sex and body condition were assessed. No significance association was observed with respect to age and sex. There were previous reports showing higher prevalence in adult animals as compared to young animals which is believed to be due to high preference of tsetse for adult animals and less exposure of young animals to tsetse challenge as they are usually kept at homestead (Torr et al., 2001; Cherenet et al., 2006). This was not seen in the present study probably due to relatively low prevalence of the tsetse transmitted trypanosome ( $T$. congolense). Significant association was also observed between body condition score and infection rate. However it would be difficult to conclude either poor body condition predispose to trypanosome infection or trypanosome infection cause loss of body condition based on such 
cross-sectional study (Dohoo et al., 2003), and it should be verified by using a longitudinal study designs.

A significant reduction in PCV was observed in the trypanosome infected animals signifying anemia to be one of the important consequence of infection. This seems an established fact that it was similarly reported by many studies both at individual animal and herd level (Van den Bossche and Rowlands, 2001; Shimels Dagnachew et al., 2005; Cherenet et al., 2006, Alekaw Sinshaw et al., 2006; Solomon Mekuria and Fitta Gadissa, 2011; Mollalign Bitew et al., 2011 ). In the present study it was also noted animals which were infected with $T$. congolense have much lower PCV values than T. vivax suggesting the higher impact of T. congolense in terms of blood pathology as compared to T.vivax.

In conclusion bovine trypanosomosis caused by $T$. congolense and $T$. vivax with more prevalence of $T$. vivax was found to be an important disease of cattle in the study area. The sole presence of $T$. vivax in the midland area indicated the importance of mechanically transmitted trypanosome in the study area. The observed association between reduction in PCV and body condition with infection showed the impact of the disease on productivity of infected animals. Control efforts in the study area should target both cyclically and mechanically transmitted trypanosome infections.

\section{References}

Abebe, G., and Jobre, Y., 1996. Trypanosomosis: a threat to cattle production in Ethiopia. Revue de Médecine Vétérinaire, 147, 897-902.

Bitew, M., Amedie, Y., Abebe, S., Tolosa,T., 2011. Prevalence of bovine trypanosomosis in selected areas of Jabi Tehenan district, West Gojam of Amhara regional state, Northwestern, Ethiopia. African Journal of Agricultural Research, 6(1), 140-144.

Cherenet, T., Sani, R.A., Speybroeck, N., Panandam, J.M., Nadzr,S., Van den Bossche, P., 2006. A comparative longitudinal study of bovine trypanosomiasis in tsetse-free and tsetse-infested zones of the Amhara Region, northwest Ethiopia. Veterinary Parasitology, 140, 251-258.

Dagnachew, S., Sangwan, A.K., Abebe, G. 2005. Epidemiology of Bovine Trypanosomosis in the Abay (Blue Nile) Basin Areas of Northwest Ethiopia. Revue Élev. Méd. vét. Pays trop., 58 (3), 151-157 
Dagnachew, Z., 1982. Trypanosomiasis in Ethiopia. In : Proceedings of the 3rd International Symposium on Veterinary Epidemiology and Economics, 1982. Pp 469-473

Dohoo, I., Martin, W., Stryhn, H., 2003. Veterinary Epidemiologic Research. AVC inc., charlottetown, price Edwards island, Canada. P 145

Mekuria, S. and Gadissa, F., 2011. Survey on bovine trypanosomosis and its vector in Metekel and Awi zones of Northwest Ethiopia. Acta Tropica, 117, 146-151

Mihret, A., Mamo, G., 2007. Bovine Trypanosomosis in three districts of East Gojjam Zone, bordering the Blue Nile River in Ethiopia. J Infect Developing Countries, 1, 321-325.

MOARD, 2005. Standard veterinary diagnostic manual. Volume III: Parasitology. Ministry of agriculture and rural development(MOARD), Addis Ababa, Ethiopia. pp 29-30

Nicholson, M.J., and Dutterworth, M.H., 1986. A Guide to Condition Scoring of Zebu Cattle. International livestock centre for Africa, Addis ababa, Ethiopia

OWWARD, 2004. Office of Wemberma Wereda agricultural and rural development wereda profile document.

Paris, J., Murray, M., McOimba,F., 1982. A comparative evaluation of the parasitological techniques currently available for the diagnosis of African animal rypanosomosis in cattle. Acta Torp, 30, 307-316.

Sinshaw, A., Abebe, G., Desquesnes, M., Yoni, W., 2006. Biting flies and Trypanosoma vivax infection in three highland districts bordering Lake Tana, Ethiopia. Veterinary Parasitology, 142, 35-46.

Stata Corporation, 1985-2001. Stata Corporation, 702 university drive east, college station, TX 77840 USA.

Thrusfield, M., 2005. Veterinary Epidemiology. $3^{\text {rd }}$ ed. Blackwell science ltd, Oxford, UK. P233.

Torr, S.J., Wilson, P.J., Schofield, S., Mangwiro, T.N.C., Akber, S.,White, B.N., 2001. Application of DNA markers to identify the individual-specific host of tsetse feeding on cattle. Med. Vet. Entomol., 15, 78-86.

Van den Bossche, P., Rowlands, G.J., 2001. The relationship between the parasitological prevalence of trypanosomal infections in cattle and herd average packed cell volume. Acta Tropica, 78, 163-170. 